\title{
Studi Analisa Kekeringan Metode Standardized Precipitation Index (SPI) dan Palmer Drought Severity Index (PDSI) di DAS Kemuning Kabupaten Sampang
}

\author{
Alfian Firdaus $^{1 *}$, Donny Harisuseno ${ }^{1}$, Ery Suhartanto ${ }^{1}$ \\ Jurusan Teknik Pengairan, Fakultas Teknik, Universitas Brawijaya \\ JI. MT. Haryono No.167, Malang, 65145 Indonesia \\ *Korespondensi Email: firdausalfian36@gmail.com
}

\begin{abstract}
Drought is a natural disaster that occurs slowly but harms Sampang Regency people's life sustainability. Consider the negative impact of drought, analyze the drought index and its distribution are necessary. This study aims to know drought level using Standardized Precipitation Index (SPI) and Palmer Drought Severity Index (PDSI), then to know their correlation with Southern Oscillation Index (SOI) that can represent El Nino Southern Oscillation (ENSO). Drought index with bigger correlation mapped by Inverse Distance Weighting method to know the distribution. SPI method produced the most severe drought in April 2004 on one month deficit period (-3.651). PDSI method developed the most severe drought in September 2001 (-20.628). Based on the PDSI average analysis results for the 19982017 period, it is well-known that drought disasters generally start in July and end in October, while the peak of drought occurs in September. The PDSI method has 60\% conformity to the SOI value derived from the graphical visualization of the annual average surplus and deficit index, better than the SPI method that only scores 53\%. The visualization of the drought distribution map shows that the Districts of Sampang, Torjun, and Camplong need to become prioritized to mitigate future drought disasters because they have a great potential for drought disasters compared to other districts.
\end{abstract}

Keywords: Distribution Map, Drought, Palmer Drought Severity Index (PDSI), Standardized Precipitation Index (SPI).

Abstrak: Kekeringan ialah bencana alam yang terjadi secara perlahan dan berdampak buruk untuk kelangsungan hidup penduduk Kabupaten Sampang. Mengingat hal tersebut, perlu dilakukan analisa indeks kekeringan serta pemetaan sebarannya sebagai upaya mitigasi bencana kekeringan. Studi ini bertujuan untuk mengetahui tingkat keparahan kekeringan dengan metode Standardized Precipitation Index (SPI) dan Palmer Drought Severity Index (PDSI), serta kesesuaiannya dengan data Southern Oscillation Index (SOI) yang mampu mempresentasikan kejadian El Nino Southern Oscillation (ENSO). Setelah itu, Indeks kekeringan yang lebih sesuai dengan pola SOI dipetakan dengan metode Inverse Distance Weighting (IDW) untuk mengetahui sebaran kekeringan. Metode SPI menghasilkan indeks kekeringan terparah di bulan April 2004 sebesar -3,651 pada periode defisit 1 bulanan. Metode PDSI menghasilkan indeks kekeringan terparah di bulan September 2001 sebesar 20,628. Berdasarkan hasil analisa rerata PDSI periode 1998-2017, diketahui bahwa 
bencana kekeringan umumnya bermula sejak bulan Juli dan berakhir di bulan Oktober, sedangkan puncak kekeringan terjadi pada bulan September. Metode PDSI juga memiliki kesesuaian sebesar $60 \%$ terhadap nilai SOI berdasarkan penggambaran grafik surplus dan defisit indeks rerata tahunan, lebih baik daripada metode SPI yang hanya bernilai 53\%. Penggambaran peta sebaran kekeringan berdasarkan indeks kekeringan PDSI menunjukkan bahwa Kecamatan Sampang, Torjun, dan Camplong perlu diprioritaskan dalam upaya mitigasi bencana kekeringan di masa mendatang karena memiliki potensi bencana kekeringan lebih besar jika dibandingan kecamatan lainnya.

Kata kunci: Indeks Kekeringan, Palmer Drought Severity Index (PDSI), Peta Sebaran Kekeringan, Standardized Precipitation Index (SPI).

\section{Pendahuluan}

Kekeringan merupakan kondisi berkurangnya ketersediaan air maupun kelembaban dengan jangka waktu sementara secara signifikan dibawah normal atau jumlah yang diharapkan pada waktu tertentu (Reed, 1995). [1] Kekeringan juga dapat tergambar dari kondisi penyimpangan dari kondisi normal hidrologis pada suatu wilayah (Palmer, 1965). [2] Fenomena El Nino berkontribusi besar pada peningkatan kejadian iklim ekstrem yang berakibat bencana kekeringan di sebagian besar daerah Indonesia (Meinke dan Boer, 2002). [3]

Badan Penanggulangan Bencana Daerah (BPBD) Kabupaten Sampang menetapkan sejumlah 64 desa yang berada di 9 kecamatan mengalami bencana kekeringan. Ketersediaan air baik di permukaan maupun dalam tanah tidak dapat memenuhi kebutuhan domestik dan pertanian penduduk setempat. Berdasarkan kejadian tersebut, perlu adanya analisa indeks kekeringan serta pemetaan sebaran kekeringan sebagai langkah awal upaya mitigasi bencana kekeringan.

Analisa indeks kekeringan dan pemetaan sebaran kekeringan telah banyak dilakukan di berbagai daerah sehingga nantinya dampak bahaya kekeringan dapat tereduksi. Rini Febriyanti (2015) melakukan studi untuk mengetahui tingkat kekeringan dengan metode Palmer Drought Severity Index (PDSI) pada Sub DAS Babak Kabupaten Lombok Tengah menyimpulkan bahwa Dari hasil komparasi peristiwa El Nino tahun 1994 hinggga 2013 dengan peristiwa kekeringan di lokasi penelitian tahun 1994 hingga 2013 memiliki prosentase kesesuaian sebesar 75\%. Jianqing Zhai (2009) menggunakan metode Palmer Drought Severity Index (PDSI) dan Standardized Precipitation Index (SPI) untuk mengetahui hubungan kejadian kekeringan dengan anomali limpasan 6 sungai besar (Songhuajiang, Liaohe, Yellow, Huaihe, Yangtze, dan Pearl) di Cina dan didapat korelasi yang relatif tinggi dan signifikan. Kesesuaian ini bermanfaat untuk mengevaluasi ketersediaan sumber daya air di Cina.

Studi ini diharapkan dapat merepresentasi peristiwa kekeringan dalam kurun waktu 1998 hingga 2007 berdasarkan nilai indeks kekeringan di DAS Kemuning dengan metode Palmer Drought Severity Index (PDSI) dan Standardized Precipitation Index (SPI) dan bagaimana hubungannya dengan Southern Oscillation Index (SOI) fenomena El Nino Southern Oscillation (ENSO) yang direpresentasikan dengan Southern Oscillation Index (SOI) yang mampu mempresentasikan kejadian El Nino Southern Oscillation (ENSO). Indeks kekeringan yang memiliki kesesuaian lebih tinggi dengan data SOI akan dipetakan dengan metode Inverse Distance Weighting (IDW) dengan bantuan perangkat lunak ArcGIS.

\section{Bahan dan Metode}

\subsection{Lokasi Studi}

DAS Kemuning merupakan yang terbesar di Kabupaten Sampang dan berlokasi pada $113^{\circ} 12^{\prime} 42^{\prime \prime}$ $-113^{\circ} 20^{\prime} 28^{\prime \prime}$ BT dan 6 $59^{\prime}$ hingga $7^{\circ} 13^{\prime}$ LS. Topografi DAS Kemuning berada pada elevasi +1 
hingga +150 . Luas Daerah Aliran Sungai (DAS) Sungai Kemuning adalah $356,19 \mathrm{~km}^{2}$. Kabupaten Sampang berada di Pulau Madura, Provinsi Jawa Timur.

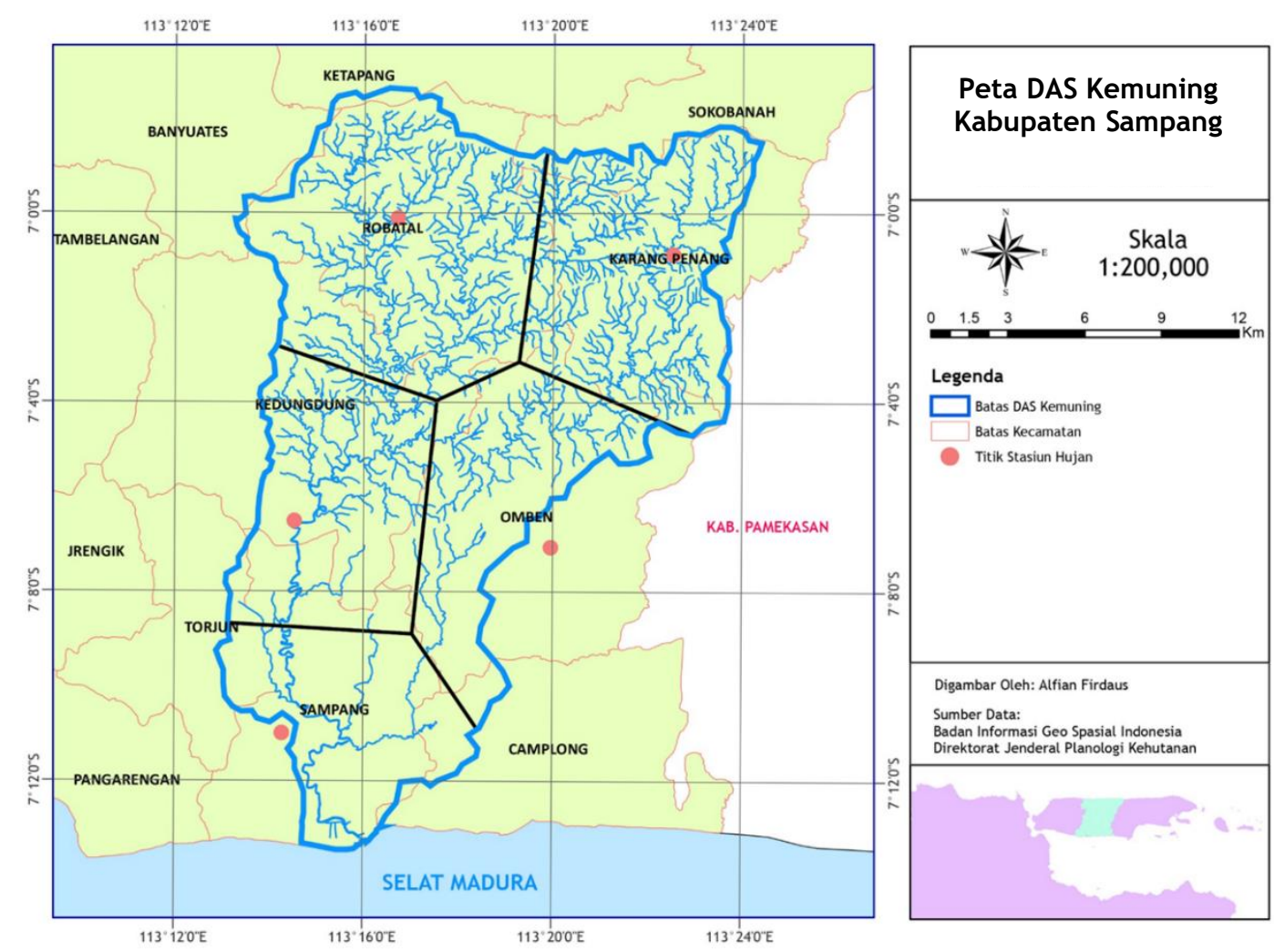

\section{Gambar 1: Peta DAS Kemuning Kabupaten Sampang}

2.2 Pengumpulan Data

Data yang dibutuhkan dalam studi ini ialah sebagai berikut:

a. Curah hujan bulanan 1998-2017

b. Suhu udara bulanan $1998-2017$

c. Nilai Southern Oscillation Index (SOI) bulanan 1998-2017

d. Peta Daerah Aliran Sungai Kemuning

e. Peta lokasi stasiun hujan

f. Peta tata guna lahan Kabupaten Sampang

g. Peta tekstur tanah Pulau Madura

h. Peta administrasi Kabupaten Sampang

\subsection{Tahapan Penyelesaian Studi}

\subsubsection{Analisa Data Klimatologi}

a. Mengumpulkan data sekunder

b. Uji statistik data curah hujan

1. Pengujian konsistensi dengan metode kurva massa ganda

2. Pengujian stasioner dengan uji $\mathrm{F}$ dan uji $\mathrm{T}$

c. Estimasi suhu udara rerata bulanan untuk setiap stasiun

d. Perhitungan evapotransporasi potensial

e. Perhitungan kapasitas penyimpanan air DAS Kemuning 


\subsubsection{Analisa Indeks Kekeringan}

a. Standardized Precipitation Index (SPI)

b. Palmer Drought Severity Index (PDSI)

2.3.3 Analisa Indeks Kekeringan

a. Analisa korelasi dan determinasi

b. Perbandingan nilai surplus dan defisit indeks kekeringan dengan data SOI

2.3.4 Penggambaran Peta Sebaran Kekeringan dengan metode Inverse Distance Weighting (IDW).

\subsection{Metode Standardized Precipitation Index (SPI)}

Standardized Precipitation Index ialah sebuah metode analisa kekeringan meteorologis yang ditemukan Thomas B. McKee tahun 1993. Metode ini mampu menghasilkan indeks kekeringan berlandaskan defisit curah hujan berbagai periode berdasarkan periode normalnya. Metode SPI dapat memberi perbandingan andal dan relatif mudah diaplikasikan untuk segala daerah dengan kondisi iklim yang berbeda (Bordi, 2009)

Analisa nilai SPI berdasarkan jumlah sebaran gamma terdefinisi sebagai fungsi frekuensi.

$$
G(x)=\int_{0}^{x} g(x) d x=\frac{1}{\beta^{\alpha} \Gamma(\alpha)} \int_{0}^{x} x^{a-1} e^{\frac{-x}{\beta}} d x \quad \text { Pers. } 1
$$

Mengestimasi Nilai $\alpha$ dan $\beta$ pada setiap stasiun curah hujan menggunakan rumus berikut:

$$
\begin{array}{lll}
\alpha & =\frac{1}{4 A}\left(1+\sqrt{1+\frac{4 A}{3}}\right) & \text { Pers. 2 } \\
A & =\ln (\bar{x})-\frac{\Sigma \ln (x)}{n} & \text { Pers.3 }
\end{array}
$$

Atau: untuk $\mathrm{x}>0$.

$$
\begin{array}{lll}
\alpha=\frac{\overline{x^{2}}}{s^{2}} & \text { Pers. } 4 \\
\beta & =\frac{\bar{x}}{\alpha} & \text { Pers. } 5
\end{array}
$$

jika $\mathrm{x}=0$, nilai $G(x)$ menjadi sebagai berikut:

$$
H(x)=q+(1-q) \cdot G(x) \quad \text { Pers. } 6
$$

$q$ merupakan total kejadian hujan bernilai $0 \mathrm{~mm}(m)$ dibagi dengan jumlah data $(n)$

nilai SPI transformasi distribusi gamma $(G(x))$ perlu ditransformasi menjadi distribusi standar normal dengan rerata 0 (nol) dan perbedaan 1 , terdapat alternatif perhitungan dengan persamaan berikut:

$$
\begin{array}{ll}
Z & =S P I=-\left(t-\frac{c_{0}+c_{1} t+c_{2} t^{2}}{1+d_{1} t+d_{2} t+d_{3} t^{3}}\right) \text { untuk } 0<H(x) \leq 0,5 \quad \text { Pers. } 7 \\
Z & =S P I=+\left(t-\frac{c_{0}+c_{1} t+c_{2} t^{2}}{1+d_{1} t+d_{2} t+d_{3} t^{3}}\right) \text { untuk } 0,5<H(x) \leq 1,0 \quad \text { Pers. } 8
\end{array}
$$


dengan:

$$
\begin{aligned}
t & =\sqrt{\ln \left(\frac{1}{(H(x))^{2}}\right)} \text { untuk } 0<H(x) \leq 0,5 \quad \text { Pers. } 9 \\
t & =\sqrt{\ln \left(\frac{1}{(1-H(x))^{2}}\right)} \text { untuk } 0<H(x) \leq 1,0 \quad \text { Pers. } 10
\end{aligned}
$$

dimana:

$$
\begin{array}{llll}
c_{0} & =2,515517 & d_{1} & =1,432788 \\
c_{1} & =0,802853 & d_{2} & =0,189269 \\
c_{2} & =0,010328 & d_{3} & =0,001308
\end{array}
$$

\subsection{Metode Palmer Drought Severity Index (PDSI)}

Wayne Palmer pada tahun 1965 mengembangkan metode perhitungan indeks kekeringan berdasarkan teori neraca air dengan mempertimbangkan nilai curah hujan, kapasitas air tanah, limpasan, dan evapotranspirasi potensial. Metode tersebut ia namai Palmer Drought Severity Index (PDSI).

Ketersediaan air tanah merupakan variabel utama pada metode PDSI. Metode yang diterapkan guna menduga ketersediaan air tanah ialah dengan menghitung luasan vegetasi penutup pada setiap luasan polygon.

2.5.1 Analisa Evapotranspirasi Potensial Metode Thornthwaite

$$
\begin{array}{cc}
E T_{x}=16 \times\left(\frac{10 \times T}{I}\right)^{a} & \text { Pers. } 11 \\
E T \quad=E T_{x} \times \text { faktor } f & \text { Pers. } 12 \\
I \quad=\sum_{i=1}^{12}\left(\frac{T}{5}\right)^{1,514} & \text { Pers. } 13 \\
a \quad=\left(6,75.10^{-7}\right) \times I^{3}-\left(7,71.10^{-5}\right) \times I^{2}+\left(1,792.10^{-2}\right) \times I+0,4924 & \text { Pers. } 14
\end{array}
$$

dengan:

$T=$ suhu udara rerata setiap bulan $\left({ }^{\circ} \mathrm{C}\right)$

$f \quad=$ koefisien penyesuaian kombinasi jumlah jam dan hari terang suatu lokasi

$I \quad=$ indeks panas tahunan

$i \quad=$ indeks panas bulanan

$E T_{x}=$ evapotranspirasi potensial sebelum disesuaikan faktor $f(\mathrm{~mm} / \mathrm{bulan})$

$E T=$ evapotranspirasi potensial $(\mathrm{mm} / \mathrm{bulan})$

\subsubsection{Analisa Water Holding Capacity (Kapasitas Penyimpanan Air)}

Water Holding Capacity (Kapasitas Penyimpanan Air)merupakan jumlah air maksimum yang dapat ditampung oleh tanah. Kondisi seperti ini dapat tercapai apabila pemberian air pada tanah sampai terjadi kelebihan air, air yang berlebih akan melimpas. Rongga tanah penuh terisi air pada kondisi ini. Tekstur 
tanah dan vegetasi penutup lahan merupakan faktor utama pada kapasitas penyimpanan air (water holding capacity).

\subsubsection{Perhitungan Neraca Air Metode Thornthwaite}

Lengas tanah pada lapisan atas mustahil untuk turun ke lapisan bawah sebelum dalam keaadan jenuh, lengas di lapisan bawah tidak bisa menguap jika masih terdapat lengas di lapisan. Neraca air metode Thornthwaite mampu menghasilkan nilai parameter untuk analisa indeks kekeringan metode PDSI seperti berikut:
a. Evapotranspirasi aktual $(A E)$
b. Surplus $(S)$
c. Limpasan $(R o)$
d. Pengisian lengas tanah potensial $(P R)$
e. Pengisian lengas tanah $(R)$
f. Kehilangan lengas tanah potensial $(P L)$
g. Kehilangan lengas tanah $(L)$

\subsubsection{Penentuan Nilai CAFEC (Climatically Appropriate for Existing Condition)}

Neraca air Thornthwaite digunakan untuk menghitung konstanta yang mendefinisikan karakteristik iklim sebagai berikut:

a. Menghitung koefisien evapotranspirasi

$$
\alpha=\overline{A E} / \overline{E T}
$$

Pers. 15

b. Menghitung koefisien pengisian lengas kedalam tanah

$$
\beta=\bar{R} / \overline{P R} \quad \text { Pers. } 16
$$

c. Menghitung koefisien kehilangan air

$$
\gamma=\overline{R o} / \bar{S}
$$

Pers. 17

d. Menghitung koefisien kehilangan air

$$
\delta=\bar{L} / \overline{P L}
$$

Pers. 18

e. Menghitung pendekatan terhadap pembobot iklim

$$
K=(\overline{E T} / \bar{R}) /(\bar{P} / \bar{L})
$$

Pers. 19

Koefisien iklim diatas digunakan untuk menduga nilai hujan atau presipitasi pada beberapa bulan sebelumnya sebagaimana dianggap sebagai keadaan normal mengacu pada pasokan air yang ada. Persamaannya sebagai berikut:

$$
\hat{P}=(\alpha x E T)+(\beta x P R)+(\gamma \times R o)-(\delta x P L) \quad \text { Pers. } 20
$$

\subsubsection{Penentuan Indeks Kekeringan PDSI}

a. Penenetuan periode kelebihan atau kekerungan hujan

$$
d=P-\hat{P}
$$

Pers. 21

b. Rerata nilai mutlak

$$
D=\text { rataan nilai } d
$$

Pers. 22 
c. Pendekatan kedua terhadap nilai faktor $K\left(K^{\prime}\right)$

$$
\begin{array}{cc}
K^{\prime}=1,5 \log 10\left(\frac{\frac{P E+R+R o}{P+L}+2,80}{\bar{D}}\right)+0,5 & \text { Pers. } 23 \\
D K^{\prime}=\bar{D} \times K^{\prime} & \text { Pers. } 24
\end{array}
$$

d. Indeks penyimpangan lengas $(Z)$

$$
Z=d x K
$$

Pers. 25

a. Indeks Kekeringan PDSI

$$
\begin{array}{ccc} 
& \text { PDSI }=\left(\frac{Z}{3}\right)_{j-1}+\Delta x & \text { Pers. 26 } \\
\Delta x & =(Z / 3)_{j}-0,103(Z / 3)_{j-1} & \text { Pers. 27 }
\end{array}
$$

dengan:

$Z \quad=$ indeks anomali lengas

$d \quad=$ nilai yang merepresentasikan periode kekurangan ataupun kelebihan hujan

$K \quad=$ faktor bobot karakteristik iklim

defisit antara nilai curah hujan hasil pengamatan di lapangan dengan curah hujan hasil pendugaan dilambangkan dengan huruf $d$. Defisit tersebut selanjutnya kalikan dengan faktor bobot karakteristik iklim $(K)$ untuk mendapatkan nilai indeks anomalis lengas $(Z)$. Indeks kekeringan bergantung pada nilai tersebut.

Nilai $(Z / 3)$ adalah keparahan kekeringan dalam rentang waktu sebulan. $\left(-0,103 \times(Z / 3)_{j-1}\right)$ merupakan formula untuk mengetahui tingkat keparahan peristiwa kekeringan. 0,103 diperoleh dari rumus jumlah penyimpangan atau anomali kejadian kekeringan yang diturunkan dan dibuthkan untuk mengetahui parahnya kekeringan yang terjadi sehingga diperoleh tingkat perubahan keparahan kekeringan dalam mengetahaui indeks kekeringan Palmer (Palmer, 1965).

Tabel 1: Klasifikasi Kekeringan Metode SPI dan PDSI

\begin{tabular}{cccc}
\hline Kelas & Klasifikasi & Nilai SPI & Nilai PDSI \\
\hline 1 & Amat Sangat Basah & $>2,00$ & $>4,00$ \\
2 & Sangat Basah & $1,50-2,00$ & $3,00-3,99$ \\
3 & Cukup Basah & $1,00-1,49$ & $1,50-2,99$ \\
4 & Mendekati Normal & $(-0,99)-0,99$ & $(-1,49)-(1,49)$ \\
5 & Cukup Kering & $(-1,00)-(-1,49)$ & $(-1,5)-(-2,99)$ \\
6 & Sangat Kering & $(1,50)-(-1,99)$ & $(-3,00)-(-3,99)$ \\
7 & Amat Sangat Kering & $<(-2,00)$ & $<(-4,00)$ \\
\hline
\end{tabular}




\subsection{El Nino Southern Oscillation (ENSO)}

El Nino Southern Oscillation (ENSO) ialah fenomena laut beserta atmosfer yang terjadi secara tidak teratur dengan berbasis pada suhu permukaan laut yang mengalami peningkatan di Samudera Pasifik bagian timur laut.

Fenomena El Nino berkontribusi besar pada peningkatan kejadian iklim ekstrem yang berakibat bencana kekeringan di sebagian besar daerah Indonesia (Meinke dan Boer, 2002).

\subsection{Metode Inverse Distance Weighting (IDW).}

Metode Inverse Distance Weighting (IDW) menerapkan asumsi suatu titik yang berdekatan memiliki keserupaan yang lebih tinggi daripada titik yang saling berjauhan. Untuk menaksir nilai di suatu lokasi, IDW akan memakai nilai dari beberapa titik acuan yang berada di sekitar lokasi. IDW mengasumsikan bahwa tingkat korelasi antar titik yang ditaksir dengan data penaksir proporsional terhadap jarak. Bobot akan berubah secara linier, sebagai fungsi jarak, disesuaikan dengan jarak terhadap penaksir (Alamsi, 2014)

\section{Hasil dan Pembahasan}

\subsection{Analisa Statistika Curah Hujan}

\subsubsection{Pengujian Konsistensi Metode Kurva Massa Ganda}

Uji konsistensi metode kurva massa ganda pada curah hujan di 5 stasiun di DAS Kemuning menghasilkan data yang konsisten sehingga layak digunakan pada proses analisa berikutnya.

\subsubsection{Pengujian Stasioner}

Pengujian F dan Uji T dengan derajat kepercayaan 5\% menunjukkan bahwa data curah hujan pada 5 stasiun di DAS Kemuning bersifat stabil terhadap nilai rerata dan varian.

\subsection{Analisa Indeks Kekeringan}

\subsubsection{Metode Standardized Precipitation Index (SPI)}

Analisa kekeringan dengan metode Standardized Precipitation Index (SPI) menghasilkan indeks kekeringan untuk periode 1,3,6, dan 12 bulanan

Tabel 2: Rekapitulasi Indeks Kekeringan Terparah Metode SPI

\begin{tabular}{ccccccc}
\hline \multirow{2}{*}{ Indeks SPI } & \multicolumn{4}{c}{ Stasiun Pengamatan } & \multicolumn{1}{c}{$\begin{array}{c}\text { Kering } \\
\text { Terparah }\end{array}$} \\
\cline { 2 - 6 } & Karang Penang & Robatal & Omben & Kedungdung & Sampang & $-3,306$ \\
\hline $\begin{array}{c}\text { Periode Defisit } \\
\text { 1 Bulan }\end{array}$ & $-3,306$ & $-2,860$ & $-3,555$ & $-3,651$ & $-2,991$ & Apr 2004 \\
\hline $\begin{array}{c}\text { Periode Defisit } \\
\text { 3 Bulan }\end{array}$ & $-1,938$ & $-2,704$ & $-2,986$ & $-2,384$ & $-2,361$ & $-2,361$ \\
\hline $\begin{array}{c}\text { Periode Defisit } \\
\text { 6 Bulan }\end{array}$ & $-1,921$ & $-1,710$ & $-2,207$ & $-2,061$ & $-2,655$ & $-2,655$ \\
\hline Pei 2004 & Mei 2004 & Mar 2014 & Mar 2011 & Mar 2011 & Mar 2011 \\
12 Bulan & Feb 2005 & Mei 1999 & Nov 2002 & Mei 1999 & Apr 2004 & Apr 2004 \\
\hline
\end{tabular}


Perhitungan nilai kekeringan dengan metode SPI menghasilkan indeks kekeringan terparah pada April 2004 dengan level "Amat Sangat Kering” sebesar -3,651 saat periode defisit 1 bulan di Stasiun Kedungdung.

\subsubsection{Metode Palmer Drought Severity Index (PDSI)}

Analisa indeks kekeringan dengan metode PDSI menghasilkan indeks kekeringan terparah sebesar -20,628 pada bulan September 2001 di Stasiun Sampang. Kekeringan terjadi akibat rendahnya curah hujan bulanan, namun rendahnya curah hujan bukan satu-satunya faktor penyebab kondisi kekeringan. Selain curah hujan, evapotranspirasi juga menjadi variabel penentu indeks kekeringan metode PDSI. Semakin besar selisih curah hujan dengan nilai evapotranspirasi, semakin parah juga kekeringan yang terjadi. Nilai kapasitas penyimpanan air atau water holding capacity yang relatif rendah menyebabkan cadangan air dalam tanah atas menipis dan memperburuk intensitas kekeringan.

Tabel 3: Rekapitulasi Indeks Kekeringan Terparah Metode PDSI

\begin{tabular}{cccl}
\hline Stasiun & Indeks PDSI & Waktu Kejadian & Klasifikasi \\
\hline Sampang & $-20,628$ & September 2001 & Amat Sangat Kering \\
Kedungdung & $-20,556$ & Oktober 2009 & Amat Sangat Kering \\
Omben & $-16,008$ & Oktober 2005 & Amat Sangat Kering \\
Robatal & $-15,436$ & September 2008 & Amat Sangat Kering \\
Karang Penang & $-20,001$ & Oktober 2009 & Amat Sangat Kering \\
\hline
\end{tabular}

Nilai PDSI di DAS Kemuning didapat dengan menghitung rata-rata nilai indeks 5 stasiun pengamatan. Berdasarkan hasil analisa rerata PDSI periode 1998-2017, diketahui bahwa bencana kekeringan sejak bulan Juli serta berakhir di bulan Oktober (kondisi kekeringan apabila indeks bernilai $<-1,5)$. Puncak kekeringan terjadi di bulan September.

Tabel 4: Rekapitulasi Indeks Kekeringan Terparah Metode PDSI

\begin{tabular}{|c|c|c|c|c|c|c|c|c|c|c|c|c|}
\hline \multirow{2}{*}{ Stasiun } & \multicolumn{12}{|c|}{ Indeks PDSI Bulanan Rerata Periode 1998-2017 } \\
\hline & Jan & Feb & Mar & Apr & Mei & Jun & Jul & Agu & Sep & Okt & Nov & Des \\
\hline Sampang & 9,154 & 10,799 & 9,408 & 6,896 & 3,537 & $-0,895$ & $-3,887$ & $-5,895$ & $-7,756$ & $-6,203$ & $-0,533$ & 4,959 \\
\hline $\begin{array}{l}\text { Kedung- } \\
\text { dung }\end{array}$ & 5,989 & 7,608 & 8,785 & 6,476 & 2,462 & $-0,710$ & $-3,398$ & $-5,936$ & $-6,817$ & $-6,551$ & $-0,456$ & 4,971 \\
\hline Omben & 8,931 & 10,923 & 10,840 & 8,639 & 4,045 & $-0,749$ & $-3,880$ & $-5,774$ & $-6,160$ & $-5,836$ & $-1,076$ & 5,423 \\
\hline Robatal & 6,193 & 7,820 & 6,831 & 6,980 & 3,947 & $-0,552$ & $-2,769$ & $-5,391$ & $-6,374$ & $-4,471$ & 0,870 & 5,409 \\
\hline $\begin{array}{l}\text { Karang } \\
\text { Penang }\end{array}$ & 6,933 & 13,936 & 11,758 & 8,623 & 3,502 & $-1,106$ & $-4,673$ & $-6,542$ & $-7,180$ & $-5,776$ & 0,227 & 12,487 \\
\hline Rerata & 7,440 & 10,217 & 9,524 & 7,523 & 3,499 & $-0,802$ & $-3,721$ & $-5,907$ & $-6,857$ & $-5,767$ & $-0,194$ & 6,650 \\
\hline
\end{tabular}


3.3 Analisa Kesesuaian Indeks Kekeringan Metode Standardized Precipitation Index (SPI) dan Palmer Drought Severity Index (PDSI) dengan Fenomena El Nino Southern Oscillation (ENSO)

\subsubsection{Metode Korelasi dan Determinasi}

Analisa korelasi dan determinasi digunakan untuk mengetahui kekuatan kesesuaian antara metode SPI dan PDSI dengan SOI secara kuantitatif. Dalam analisanya kita memerlukan data SPI, PDSI, dan SOI bulanan yang telah ditransformasi ke bentuk distribusi normal. Tujuan dari analisa ini ialah mengetahui kesesuaian kejadian kekeringan dengan fenomena ENSO skala waktu bulanan.

Tabel 5: Rekapitulasi Indeks Kekeringan Terparah Metode PDSI

\begin{tabular}{ccccccc}
\hline \multirow{2}{*}{ Metode } & \multicolumn{6}{c}{ Nilai Korelasi Determinasi Indeks Kekeringan setiap Stasiun terhadap SOI } \\
\cline { 2 - 6 } & Sampang & Robatal & Kedungdung & Omben & Karang Penang & Rerata \\
\hline SPI 1 dan SOI & 0,035 & 0,026 & 0,006 & 0,015 & 0,023 & 0,021 \\
PDSI dan SOI & 0,011 & 0,001 & 0,001 & 0,001 & 0,004 & 0,003 \\
\hline
\end{tabular}

Berdasarkan perhitungan, diperoleh kesesuaian yang amat sangat lemah antara indeks kekeringan SPI dan PDSI dengan data SOI selama periode 20 tahun sehingga tidak mampu mendeskripsikan keterkaitan antara keduanya.

\subsubsection{Analisa Persen Kesesuaian Metode SPI dan PDSI dengan SOI}

Analisa persen kesesuaian mampu memberi nilai korelasi berdasarkan kesesuian surplus dan defisit nilai rerata tahunan SPI periode defisit 1 bulanan dan PDSI pada stasisun pengamatan dengan nilai rerata tahunan SOI periode 1998-2017 yang telah ditransformasikan ke bentuk normal. tujuan dari analisa ini ialah mengetahui kesesuaian kejadian kekeringan dengan fenomena ENSO skala waktu tahunan.

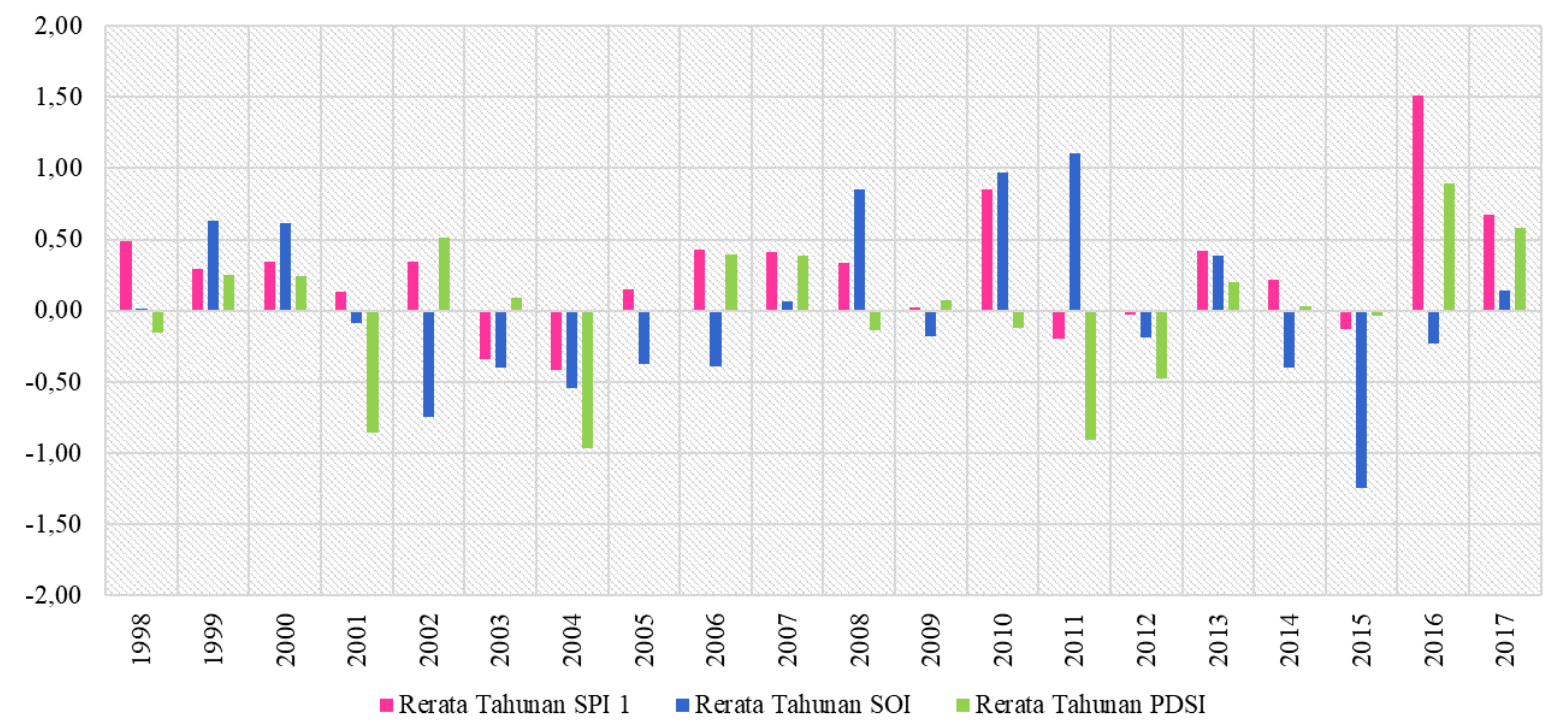

Gambar 2: Grafik Surplus dan Defisit Rerata Tahunan SPI dengan SOI Stasiun Sampang 
Tabel 6: Rekapitulasi Kesesuian Grafik Surplus dan Defisit SPI dan PDSI dengan SOI

\begin{tabular}{ccccc}
\hline \multirow{2}{*}{ Stasiun } & \multicolumn{2}{c}{ SPI } & \multicolumn{2}{c}{ PDSI } \\
\cline { 2 - 5 } & $\begin{array}{c}\text { Banyak } \\
\text { Kesesuaian }\end{array}$ & $\begin{array}{c}\text { Persen } \\
\text { Kesesuaian (\%) }\end{array}$ & $\begin{array}{c}\text { Banyak } \\
\text { Kesesuaian }\end{array}$ & $\begin{array}{c}\text { Persen } \\
\text { Kesesuaian (\%) }\end{array}$ \\
\hline Sampang & 12 & 60 & 10 & 50 \\
Robatal & 10 & 50 & 11 & 55 \\
Kedungudung & 8 & 40 & 12 & 60 \\
Omben & 10 & 50 & 14 & 70 \\
Karang Penang & 13 & 65 & 13 & 65 \\
\hline Rerata & & $\mathbf{5 3}$ &
\end{tabular}

Metode PDSI memiliki nilai persen kesesuian (60\%) yang lebih tinggi terhadap nilai SOI jika dibandingkan metode SPI (53\%).

\subsubsection{Analisa Pola Kesesuaian Metode SPI dan PDSI dengan Data Curah Hujan Bulanan}

Untuk mengetahui kelayakan pengaplikasian metode SPI dan PDSI di lapangan, maka perlu juga mengetahui kesesuaian indeks kekeringan dengan data curah hujan bulanan. Kesesuaian akan terjadi apabila bulan kekeringan terparah pada nilai SPI dan PDSI terjadi bersamaan dengan bulan yang memiliki hujan minimum selama setahun.

Tabel 7: Kesesuaian Indeks SPI dan PDSI dengan Curah Hujan

\begin{tabular}{|c|c|c|c|c|}
\hline \multirow[b]{2}{*}{ Stasiun } & \multicolumn{2}{|c|}{ SPI } & \multicolumn{2}{|c|}{ PDSI } \\
\hline & $\begin{array}{c}\text { Banyak } \\
\text { Kesesuaian } \\
\end{array}$ & $\begin{array}{c}\text { Persen } \\
\text { Kesesuaian }(\%) \\
\end{array}$ & $\begin{array}{c}\text { Banyak } \\
\text { Kesesuaian } \\
\end{array}$ & $\begin{array}{c}\text { Persen } \\
\text { Kesesuaian }(\%) \\
\end{array}$ \\
\hline Sampang & 0 & 0 & 19 & 95 \\
\hline Robatal & 0 & 0 & 15 & 75 \\
\hline Kedungudung & 0 & 0 & 17 & 85 \\
\hline Omben & 0 & 0 & 18 & 90 \\
\hline Karang Penang & 0 & 0 & 19 & 95 \\
\hline Rerata & & $\mathbf{0}$ & & 88 \\
\hline
\end{tabular}

Metode analisa kekeringan metode PDSI memiliki kesesuaian dengan curah hujan minimum sebesar $88 \%$ sedangkan sama sekali tidak terjadi kecocokan pada metode analisa kekeringan SPI (nilai kesesuaian 0\%). Tidak adanya transformasi distribusi pada metode analisa kekeringan PDSI menjadikan tinggi rendahnya curah hujan berbanding lurus dengan indeks kekeringan.

\subsection{Analisa Pemetaan Kekeringan di DAS Kemuning}

Analisa pemetaan kekeringan di DAS Kemuning menggunakan perangkat lunak ArcMap dengan metode Inverse Distance Weighting (IDW). IDW memiliki kemampuan untuk mengestimasi nilai sebuah titik pada lokasi yang tidak tersampel dengan mengacu pada nilai data di beberapa titik pantau. 

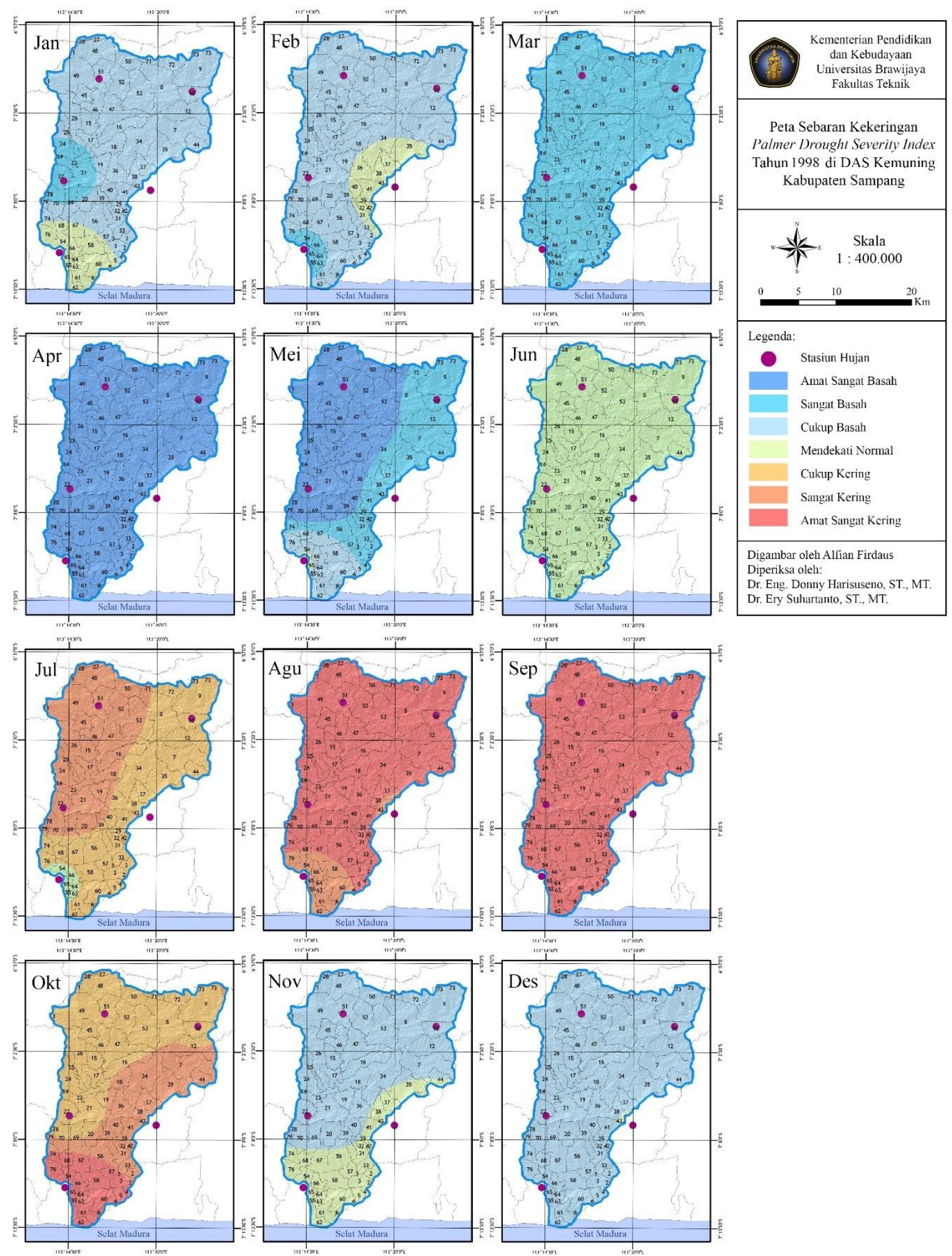

\section{Gambar 3: Peta Sebaran Kekeringan Metode PDSI Tahun 1998 di DAS Kemuning}

Berdasarkan Hasil pemeteaan kekeringan dengan metode PDSI dalam kurun waktu 20 tahun (1998 hingga 2017) menunjukkan bahwa hampir semua desa di area DAS Kemuning pernah mengalami kekeringan dengan level amat sangat kering setiap tahunnya. Puncak kekeringan selama periode 19982017 terjadi pada bulan September 
Kecamatan yang sering mengalami kekeringan terparah ialah Kecamatan Camplong, Sampang, dan Torjun dengan rerata kejadian kekeringan tingkat amat sangat kering sebanyak 68 kali dari total 240 bulan yang ada dalam periode 1998-2017. Daerah tersebut perlu diprioritaskan dalam upaya mitigasi bencana kekeringan.

\section{Kesimpulan}

Dari hasil analisis yang telah dilakukan serta terhadap simulasi keruntuhan Bendungan Malahayu dapat disimpulkan sebagai berikut:

1. Perhitungan indeks kekeringan metode Standardized Precipitation Index (SPI) menghasilkan indeks kekeringan terparah dengan level "Amat Sangat Kering" sebesar -3,651 untuk periode defisit 1 bulan pada bulan April 2004 di Stasiun Kedungdung.

2. Perhitungan indeks kekeringan metode Palmer Drought Severity Index (PDSI) menghasilkan indeks kekeringan terparah sebesar -20,628 pada bulan September 2001 di Stasiun Sampang. Kondisi kekeringan dengan klasifikasi "Cukup Kering” hingga "Amat Sangat Kering” memiliki prosentase kejadian sebesar $40 \%$. Bencana kekeringan dimulai pada bulan Juli dan berakhir pada bulan Oktober. Puncak kekeringan terjadi pada bulan September.

3. Metode PDSI menunjukkan kesesuaian dengan grafik surplus dan defisit nilai Southern Oscillation Index (SOI) sebesar 60\%, sedangkan metode SPI hanya sebesar 53\%. Maka dapat disimpulkan bahwa kesesuaian metode PDSI dengan fenomena El Nino Southern Oscillation (ENSO) lebih baik apabila dibandingkan dengan metode SPI.

4. Berdasarkan Hasil pemetaan kekeringan berbasi data PDSI dalam kurun waktu 20 tahun (1998 hingga 2017) menunjukkan bahwa hampir semua desa di area DAS Kemuning pernah mengalami kekeringan dengan level amat sangat kering setiap tahunnya. Kecamatan yang sering mengalami kekeringan terparah ialah Kecamatan Camplong, Sampang, dan Torjun dengan rerata kejadian kekeringan tingkat amat sangat kering sebanyak 68 kali dari total 240 bulan yang ada dalam periode 1998-2017. Daerah tersebut perlu diprioritaskan dalam upaya mitigasi bencana kekeringan. Kejadian kekeringan tersebut umumnya berlangsung sejak bulan Juli hingga Oktober dengan puncak kekeringan terjadi di bulan September

\section{Daftar Pustaka}

[1] Reed, Shelia B. 1995. Pengantar tentang Bahaya. Program Pelatihan Manajemen Bencana.

[2] Palmer, W.C. 1965. Meteorologic Drought. US Department of Commerce, Weather Bureau, Research Paper.

[3] Boer, R and Meinke, H. 2002. Plant Growth and the SOI, in Will It Rain? The effect of the Southern Oscillatioon and El Nino in Indonesia. Department of Primary Industries Queensland, Brisbane Australia.

[4] Limantara, Prof. Dr. Ir Lily Montarcih. 2010. Hidrologi Praktis. Bandung: CV. Lubuk Agung

[5] Soewarno. 1995. Hidrologi Aplikasi Metode Statistika untuk Analisa Data. Bandung: Nova.

[6] Sen, Zekai. 2015. Applied Drought Modeling, Prediction, and Mitigation. Jeddah: King Abdulaziz University.

[7] Rofiq Kurniawan, A., Bisri, M., Suhartanto, E. 2019. Analisa Kekeringan pada Daerah Aliran Sungai Bedadung Berbasis Sistem Informasi Geografis (Sig). Jurnal Teknik Pengairan, Vol 10, pp 97-109. Malang: Universitas Brawijaya.

[8] Harisuseno, Donny. 2020. Comperative Study of Meteorological and Hydrogical Drought characteristics in Pekalen River Basin, East Java, Indonesia. Journal of Water and Land Develeopment, No.45, 19-41, DOI: 10.24425/jwld.2020.133043. 
[9] Yu, Huiqian. dkk. 2019. Modified Palmer Drought Severity Index: Model Improvement and Application. Beijing: Beijing Normal University.

[10] Tyszkowski, Arkadiusz Bartczak Ryszard Glazik Sebastian. 2014. Application of Box-Cox Transformation to Determine Standardized Precipitation Index (SPI), Standardized Discharge Index (SDI) and to Identify Drought Events: Case Study in Eastern Kujawy (Central Poland). Journal of Water and Land Development No. 22

[11] Zhai, Jianqing. dkk. 2010. Spatial Variation and Trends ind PDSI and SPI Indices and Their Relation to Streamflow in 10 Large Regions of China. J Climate.

[12] Pramono, Gatot H. 2008. Akurasi Metode IDW dan Krigging untuk Interpolasi Sebaran Sedimen Tersuspensi di Maros, Sulawesi Selatan. Forum Geografi Vol. 22, No. 1. 